\title{
Capability of Print Media and Electronic Media in Analyzing News
}

\author{
Ahmad Qorib ${ }^{1}$, M. Yoserizal Saragih ${ }^{1}$ \\ ${ }^{I}$ Social Science Faculty, State Islamic University of Medan (UNIMED), Indonesia \\ yosesaragih77@gmail.com
}

\begin{abstract}
The scope of journalistic space usually revolves around journalistic work, news, and clarification of issues that are currently hot. The scope of this journalism applies not only in mass media, but also in electronic media such as radio and television broadcasts. Characters and its peculiarities include the aspects of the publishing philosophy, the technical dynamics of preparation and management, and the assumptions of the impact on the audience, listeners, or viewers. This chapter discusses some key aspects relating to journalism, namely the notion of journalism, at a glance the development of journalism, forms of journalism, journalistic products. The aim of this research is the activity of preparing, seeking, collecting, processing, presenting, and disseminating news through the media periodically to the widest possible audience. The research method is qualitative research.
\end{abstract}

Keywords : Journalism; Printed Media; Electronic Media

\section{Introduction}

Journalism is not only limited to print media such as newspapers, magazines, etc., but extends to electronic media such as radio or television. Based on the media used include print journalism, electronic (electronic journalism). Lately there has also been growing journalism on an online basis (online journalism). Every form of journalism has its own characteristics and characteristics. Characters and its peculiarities include the aspects of the publishing philosophy, the technical dynamics of preparation and management, and the assumptions of the impact on the audience, listeners, or viewers. This chapter discusses some key aspects relating to journalism, namely the notion of journalism, at a glance the development of journalism, forms of journalism, journalistic products.

\section{Literature Review}

\subsection{Journalism}

Etymologically, Journalism comes from the word Journal. In French, journal means notes or daily reports. Simple journalism is defined as activities related to recording or reporting every day. This journalism is not a press, not a mass media. Journalism is an activity that allows the press or mass media to work and their existence is well recognized. In dictionaries, journalism is defined as an activity to prepare, edit, and write for newspapers, magazines or other periodicals. According to Indonesian encyclopedias, journalism is a field of profession that seeks the presentation of information about events and / or daily life.

Along with the advancement of information technology, which starts from the daily report, the daily newspaper is printed. From print media to electronic media, from the advancement of electronics, information media in the form of radios are created. Not enough with radio, which is only sound, a new breakthrough in the form of audio-visual media, namely TV (television). As a free and unlimited network. And now with the development of technology has given birth to a lot of media (multimedia). 
Journalism can be limited briefly as an activity of preparation, writing, editing, and delivery of news to the public through certain media channels. Journalism covers activities from coverage to dissemination to the public. Previously, journalism in a narrow sense was also called printed publication. This understanding is not only limited to print media such as newspapers, magazines and so on, but extends to electronic media such as radio or television.

Based on the media used include print journalism (print journalism), electronics (electronic journalism). Finally, there has also been growing journalism on an online basis (online journalism). Previously journalistic activities were carried out by manual methods, ranging from news searches to news reporting activities or news gathering carried out in a very simple way. This is because in the past the tools supporting journalistic activities were still minimal. In addition, journalism in the past was only understood as printed publications. But now not only from there, electronic media also takes part in the coverage as well as mass media players.

It can be seen nowadays the world of technology is increasingly developing the development of technology also affects the development of journalism. In the past, it was only a professional journalist who was able to carry out journalistic activities. Where journalistic activities in question were seeking, collecting, processing, and reporting news to the wider community. However, at present, journalistic activities cannot only be carried out by professional journalists.

\subsection{Scope of Journalistic activities}

The scope of journalism is public relations or the field of journalistic work. The scope of journalistic space usually revolves around journalistic work, news, and clarification of issues that are currently hot. The scope of this journalism applies not only in mass media, but also in electronic media such as radio and television broadcasts.

Based on its nature, news, which is one of the journalistic scopes can be divided into two types, namely the latest news and periodic news. Before publication, each of the news items must be made or written by following a clarification about the character or writing technique. This the scope of journalistic science includes;

1. The basic concept of Journalism which includes the definition of concepts, functions and historicity of journalism.

2. The variety and character of journalism that contains the form of journalism in an implementation that is tailored to the media and journalistic trends

3. Journalist profession and its development

4. Journalistic implementation which contains sources of journalistic work, language, journalistic techniques and a variety of journalistic works

5. The spirit of morality in journalistic activities reflected in journalistic ethics.

Meanwhile, Palapah and Syamsudin in the dictate entitled Basics of Journalism divided the scope of journalism into two parts, namely News and Views.

\subsubsection{News}

News means news. News is defined as a form of nonfiction writing based on a factual event (what happens) and actual (recent event); reports on actuals facts, attract attention, are considered important, and are considered extraordinary. News itself the literal meaning is crucial or new. 
If abbreviated, NEWS is North, West, south and East. It shows that news is a news from all directions / throughout the world. It contains questions about what (what happens), who (who is involved in the news), when (when it happened), where (where is the location), why (why it happened), and how (how what happened). Or commonly abbreviated as $5 \mathrm{~W}+1 \mathrm{H}$.

There are several things until something is called news. Journalists must include the following values:

1. Objectives (in accordance with facts and impartiality)

2. Actual (new events that have occurred or are not stale)

3. Outstanding (strange, abnormal, outside general norm)

4. Important (have an influence or impact on the interests of many people)

5. Distance (the closer the incident is, the more crucial it is to the audience at the venue)

News is grouped into several forms of news, namely spot news, straight news, interpreted news, interpretative news, news stories, and others. Straight news is usually the shortest news, but still solid and answers the questions $5 \mathrm{~W}+1 \mathrm{H}$. News that is considered very crucial is usually referred to as Stop Press. If the news is broadcast on television and radio media is called breaking news, because it is broadcast on the sidelines of other events.

News can be divided into two major parts, namely Straight news is usually the shortest news, but still solid and answer the question $5 \mathrm{~W}+1 \mathrm{H}$. News that is considered very important is usually referred to as Stop Press. If the news was aired on television and radio media called breaking news, because it was broadcast on the sidelines of other events.

a. Straight news consists of:

1) Matter of fact news

2) Interpretative report

3) Reportage

b. Feature news, which consists of:

1) Human interest features

2) Historical features

3) Biographical and personality features

4) Travel features

5) Scientific features

\subsubsection{Views}

Views or views are an opinion of the person concerned about a problem or event. The view is usually conveyed by people who are experts and master the problem. The person is a person who is considered reliable and trusted to discuss issues or events that will become news.

In writing, views are usually editorial, articles, opinions, readers' letters, essays, and others. However, there is also an article that does not include news but also does not include opinions, namely features. Feature is a combination of news and views. Features can be in the form of tips, biographies, travel notes, or catching interest.

Views can be divided into several parts, namely:
a. Editorial
b. Special article
c. Colom
d. Feature article
e. History of Journalism 
According to the Lexicon Communication, mass media is a means of delivering messages that are directly related to the wider community such as radio, television, and newspapers.

Media is the plural form of a medium which means middle or intermediate. Mass comes from the English language, mass which means group or group. Thus, the notion of mass media is an intermediary or tools used by the masses in relation to each other

Which includes mass media mainly are newspapers, magazines, radio, television, and films as the Big Five of Mass Media, as well as the internet (cyber media, online media).

\section{a. Print Mass Media (Printed Media).}

Mass media printed on sheets of paper. In terms of format and size of paper, printed mass media in detail includes (a) newspapers or newspapers (broadsheet paper sizes or $1 / 2$ flipchart), (b) tabloids (1/2 broadsheet), (c) magazines (1/2 tabloids) or folio / quarto size paper, (d) books (1/2 magazine), (e) newsletters (folio / quarto, number of pages typically 48 ), and (f) bulletins (1/2 magazine, number of pages usually 4-8). The contents of the mass media are generally divided into three parts or three types of writing: news, opinions, and print feature media have characteristics, including print media are usually more flexible, easily carried everywhere can be stored (dikliping), can be read anytime, not time bound. In terms of the presentation of advertisements, although print media is in many ways less attractive and attractive than electronic media, in other aspects it can be delivered in a more informative, complete and specific manner to meet the needs of the consumer community. In addition, in terms of the delivery of social criticism through print media, it will be more weight or more effective because it is reviewed in more depth and can accommodate as much as possible the opinion of the observer and the aspirations of the community in general.

\section{b. Electronic Mass Media (Electronic Media).}

The type of mass media whose contents are disseminated through sound or image and sound using electro technology, such as radio, television, and film. Media electronics has several characteristics, namely fast in conveying information, can reach a wider audience, can show the process of occurrence of an event accompanied by direct reporting from the scene and more interesting because it is packaged with a mix of audio and visuals. Although in the presentation of information, electronic media does not carry out in-depth review of problems because it is constrained by high production processes, but through electronic media, access to information can be obtained by the public more quickly.

\section{c. Online media (online media)}

Mass media that is presented online on the internet website. Online media is "third generation" mass media after printed media, newspapers, tabloids, magazines, and electronic media (electronic media) radio, television, and film / video. Media Online is an online journalistic product. Online journalism is also called cyber journalism is defined as "reporting facts or events produced and distributed through the internet".

Technically or "physically", online media, also called Digital Media, are telecommunications and multimedia-based media (computers and the internet). Included in the online media category are portals, websites (websites, including blogs), online radio, online TV, and e-mail. 
The characteristics and advantages of online media compared to "conventional media" (print / electronic) include:

a. Broad capacity - the web page can accommodate very long manuscripts

b. Script loading and editing can be anytime and anywhere.

c. Schedule can be published at any time, at any time.

d. Fast, so uploaded can be accessed directly by everyone.

e. Reach all the world that has internet access.

f. Valid, contains actual info because of the ease and speed of presentation.

g. Updates, information updates continue and can be done at any time.

h. Interactive, two-way, and "egalitarian" with the comments of column, chat rooms, polling, etc.

i. Documented, information is stored in a "data bank" (archive) and can be found through "links", "related articles", and "search" facilities.

j. Connect with other sources (hyperlinks) related to information presented.

\section{Discussion}

The development of human civilization from time to time has resulted in an increase in work aids (the technology used). Initially the field of communication and information technology produced printing technology (mechanics), then emerged audio / radio technology (electronics), film technology (a combination of mechanics and electronics), and subsequently born audiovisual / television technology, tele / video tex, and telematics that are interactive (electronic).

Each media has advantages and disadvantages in its function as a means, but for the public, the advantages and disadvantages can complement each other in clarifying the reception of information or the contents of the message.

Through radio and television media, information can be received quickly but not in detail, while detailed information can be obtained through periodic print mass media.

Print and electronic periodic mass media have properties that are specified as a periodic mass media, namely publicity, universality, periodicity, continuity, and actuality (Baschwittz, 1946) which means:

1. Publicity: means that it can be disseminated to the public

2. Universality: the content of the message is general or universal, which means it can be read, heard or seen by anyone.

3. Periodicity: periodically or fixed to the public. Presented here means published or broadcast.

4. Continuity: presented continuously, until facts and opinions that contain news values are no longer considered important or attractive by most audiences.

5. Actuality: message content prioritizes novelty values. 
Differences in nature between periodic, print and television mass media:

\begin{tabular}{|c|c|c|}
\hline \multirow[t]{2}{*}{ Printed } & \multicolumn{2}{|c|}{ Electronics / broadcasting } \\
\hline & Radio & Television \\
\hline Printing process & Transmission Process & Transmission Process \\
\hline $\begin{array}{l}\text { The contents of the message } \\
\text { are printed, can be read } \\
\text { anywhere and anytime }\end{array}$ & $\begin{array}{l}\text { The contents of audio } \\
\text { messages, can be heard at a } \\
\text { glance when there is a } \\
\text { broadcast }\end{array}$ & $\begin{array}{l}\text { The contents of audiovisual } \\
\text { messages, can be seen and } \\
\text { heard at a glance when there is } \\
\text { a broadcast }\end{array}$ \\
\hline \multirow[t]{2}{*}{$\begin{array}{l}\text { Message content can be read } \\
\text { repeatedly }\end{array}$} & Cannot be repeated & Cannot be repeated \\
\hline & $\begin{array}{l}\text { Can present events / opinions } \\
\text { that are happening }\end{array}$ & $\begin{array}{l}\text { Can present events / opinions } \\
\text { that are happening }\end{array}$ \\
\hline $\begin{array}{l}\text { Cannot present the opinion of } \\
\text { the person directly (audio) }\end{array}$ & $\begin{array}{l}\text { Can present the opinion } \\
\text { (audio) of the resource person } \\
\text { directly / original }\end{array}$ & $\begin{array}{l}\text { Can present the opinion } \\
\text { (audio) of the resource person } \\
\text { directly / original }\end{array}$ \\
\hline $\begin{array}{l}\text { Writing is limited to columns } \\
\text { and pages }\end{array}$ & $\begin{array}{l}\text { Writing is limited by seconds, } \\
\text { minutes and hours }\end{array}$ & $\begin{array}{l}\text { Writing is limited by seconds, } \\
\text { minutes and hours }\end{array}$ \\
\hline $\begin{array}{l}\text { Periodic meaning is limited by } \\
\text { days, weeks, months }\end{array}$ & $\begin{array}{l}\text { Periodic meaning is limited by } \\
\text { seconds, minutes and hours }\end{array}$ & $\begin{array}{l}\text { Periodic meaning is limited by } \\
\text { seconds, minutes and hours }\end{array}$ \\
\hline $\begin{array}{l}\text { Distribution via land / sea and } \\
\text { air transportation }\end{array}$ & $\begin{array}{l}\text { Distribution through } \\
\text { transmission / transmission }\end{array}$ & $\begin{array}{l}\text { Distribution through } \\
\text { transmission / transmission }\end{array}$ \\
\hline $\begin{array}{l}\text { Languages used in formal } \\
\text { languages }\end{array}$ & $\begin{array}{l}\text { Languages used in formal and } \\
\text { non-formal languages (spoken } \\
\text { language) }\end{array}$ & $\begin{array}{l}\text { Languages used in formal and } \\
\text { non-formal languages (spoken } \\
\text { language) }\end{array}$ \\
\hline $\begin{array}{l}\text { The sentence can be long and } \\
\text { detailed }\end{array}$ & $\begin{array}{l}\text { Short sentences, simple and } \\
\text { clear solid }\end{array}$ & $\begin{array}{l}\text { Short sentences, simple and } \\
\text { clear solid. }\end{array}$ \\
\hline
\end{tabular}

Media Capabilities are:

1. Fixative Ability, the media can capture, store, and display an object or event again if it is needed again. The way is drawn, written, photographed, dished out, recorded.

2. Manipulative ability, an object or event using media can be changed (manipulated) its appearance (including size and / or speed) according to needs. Example: size: miniature Borobudur temple (large size of Borobudur becomes smaller); speed: the growth of corn plants starting from planting seeds to harvest, how to take pictures and then the photo is made one and accelerated

3. Distributive ability, an object or event using media can be disseminated (distributed) to a wider area with more recipients. For example: in RT, I want to announce that there are people who have died, by using microphone media in mosques, that information can be immediately disseminated

In terms of form and management, journalism is divided into three major parts: Print Media Journalism (News Paper and Magazine Journalism), Journal of Auditive Electronic Media (Radio Broadcast Journalism), Audiovisual Media Journalism (Television Journalism). Print journalism includes journalism, daily newspapers, weekly newspapers, daily tabloid journalism, weekly journalistic journalism, and journalistic magazines. Print media journalism is influenced by two factors, namely verbal and visual factors. verb strongly emphasizes our ability to choose and compose words in a series of effective and communicative sentences and paragraphs. Visual refers to our ability to organize, place, designate things or things that deny the aspect of appearance. 
The news material that we want to convey to readers is indeed very important. However, if the news is not well placed, the impact will be less significant. This is what must be considered by the visual design, layout, or display department. Print media journalism is influenced by two factors, namely verbal and visual factors. Verb strongly emphasizes our ability to choose and compile a series of effective and communicative sentences and paragraphs. Visual, refers to our ability to organize, place, design layout or things that pertain to appearance. The material of news that we want to convey to readers is indeed very important. However, if the news is not well placed, the impact will be less significant. This is what must be considered by the visual design, layout, or display department. In a journalistic perspective, not only must the information presented to the public be correct, clear and accurate but also must be interesting. Generating interest in reading (newspapers, magazines) tastes of listening (radio broadcasts), and the taste of watching (television). This is among other things that distinguishes journalistic works from other works such as scientific work. Journalistic work must be correct and packaged in interesting language and presentation. Scientific work is usually correct but not interesting.

The life of the print media is determined by "the conditions in which he lives", namely: the political system, the system of power, and the culture of power. "Any change in the political system, the press system will also change according to what power requires. In addition to following the periodic published time every morning or evening, as a daily, weekly, or monthly, and occasionally issuing special editions, the paper display also changes. For example: compass, in mid-2005 changes in size, columns, images, photos, and layout and layout of faces, also in the language of presentation and reporting style.

Similarly, the appearance of the magazine. Since the reforms began in Indonesia, many magazines have sprung up. They are pursuing people's needs for a variety of information, from mild to severe. In various news magazines, for example, journalists not only report on public events but also pursue a variety of hidden information. Journalists are sent to cover various public institutions, commercial companies, or government.

\section{a. Newspaper}

According to Dame Rebecca West, "every society needs news like people need eyes. He wants to know what everything is happening. "but, news does not always mean that. According to William Randolph Hearst, news is someone who wants to stop something they want to print. Because, advertising is more necessary. Two things that accompany the development of the modern press world. In line with the power to reach millions of readers in various parts of the world, and competition with radio and television. Electronic technology, which supplies television, has contributed to the development of the newspaper printing process. The presence of television makes the appearance of newspapers distributed free of charge. Adlan has covered the cost of printing production.

When the publication also varies, there are daily, weekly, morning or evening newspapers. The target of its distribution, there are those who want to reach several hundred residents of a small city, there are those who want to supply all people in a country or nation, even for all people in the world as international "markets". A newspaper is different from other types of publications because of its immediacy, headline characteristics, and diversity of coverage involving various topics, issues and events. However, the function of the newspaper is not just a reporter of human interested stories, from various events or events of a person. 


\section{b. Newsletter}

Newsletters are reports that are general but not always fixed. They offer a variety of personal journalism and rarely contain advertisements. According to the modern ENCYCLOPEDIA BRITANNIC The newsletter is corantos, a collection of pages of various news items quoted from various foreign journals Initially circulated in the Netherlands at the beginning of the 17th century, and English and French translations were published in Amsterdam. Boston Newsletter is also the first American newspaper to appear in 1704.

Roger W. Babson, can be considered among those who introduce the newsletter. In its development, the circulation of the newsletter had many variations, from the sheet of the Free volunteers group in small numbers to the hundreds of thousands of regular subscriptions of The Kiplinger Washington Letter, which were made by Willard M.Kiplinger since 1923. The development of newsletters is influenced by typewriters, speed and business of printing machines as well as cameras and art in the 20th century, direct and special postal items also influence. Computers and electronic shipments speed up the number and spread time.

Journalistic auditive electronic media or radio broadcast journalism, more influenced by verbal, technological, and physical dimensions. Verbal, related to the ability to compile words, sentences, and paragraphs effectively and communicatively. Technological, related to technology that allows radio transmit power to be captured clearly and clearly by radio receivers. Physical, is closely related to the level of physical health and hearing ability of audiences in absorbing and digesting faithfully the message of the word or sentence delivered.

\section{a. Radio}

Radio is a technology used for sending signals by modulation and electromagnetic radiation (electromagnetic waves). These waves pass and propagate through the air and can also propagate through empty space, because these waves do not need a transport medium (such as air molecules).

\section{b. Newsletter}

Newsletters are reports that are general but not always fixed. They offer a variety of personal journalism and rarely contain advertisements. According to the modern ENCYCLOPEDIA BRITANNIC The newsletter is corantos, a collection of pages of various news items quoted from various foreign journals Initially circulated in the Netherlands at the beginning of the 17th century, and English and French translations were published in Amsterdam. Boston Newsletter is also the first American newspaper to appear in 1704.

Roger W. Babson, can be considered among those who introduce the newsletter. In its development, the circulation of the newsletter had many variations, from the sheet of the Free volunteers group in small numbers to the hundreds of thousands of regular subscriptions of The Kiplinger Washington Letter, which were made by Willard M.Kiplinger since 1923.

The development of newsletters is influenced by typewriters, speed and business of printing machines as well as cameras and art in the 20th century, direct and special postal items also influence. Computers and electronic shipments speed up the number and spread time.

Journalistic auditive electronic media or radio broadcast journalism, more influenced by verbal, technological, and physical dimensions. Verbal, related to the ability to compile 
words, sentences, and paragraphs effectively and communicatively. Technological, related to technology that allows radio transmit power to be captured clearly and clearly by radio receivers. Physical, is closely related to the level of physical health and hearing ability of audiences in absorbing and digesting faithfully the message of the word or sentence delivered.

\section{a. Radio}

Radio is a technology used for sending signals by modulation and electromagnetic radiation (electromagnetic waves). These waves pass and propagate through the air and can also propagate through empty space, because these waves do not need a transport medium (such as air molecules).

\section{b. Radio Wave}

Radio waves are a form of electromagnetic radiation and are formed when electrically charged objects are modulated (increased frequency) at frequencies found in radio frequency (RF) frequencies in an electromagnetic spectrum. These radio waves are in the frequency range of 10 hertz $(\mathrm{Hz})$ to several gigahertz $(\mathrm{GHz})$, and electromagnetic radiation moves by electric or magnetic oscillations. Other electromagnetic waves, which have frequencies above radio waves include gamma rays, $X$-rays, infrared, ultraviolet, and visible light. When radio waves are transmitted through cables, the oscillations of the electric and magnetic fields are expressed in the form of alternating current and voltage in the cable. This can then be converted into audio signals or other information. Although the word 'radio' is used for matters relating to sound wave receivers, the wave transmission is used as the basis of waves on television, radio, radar, and mobile phones in general.

\section{c. Use of Radio}

Much of the early use of radio was maritime, to send telegraph messages using Morse code between ships and land. One of the earliest users including the Japanese Navy spied on the Russian fleet during the Tsushima War in 1901. One of the most memorable uses was at the time of the sinking of the RMS Titanic in 1912, including communication between operators on sinking ships and nearby ships, and communication to land station registering the saved. Radio was used to channel orders and communications between the Army and Navy on both sides of World War II. Germany used radio communications for diplomatic messages when its submarine cables were cut by Britain. The United States delivered Fourteen Principles of President Woodrow Wilson to Germany via radio during the war. Broadcasts can begin in 1920, with the popularity of radio aircraft, especially in Europe and the United States. Besides broadcasting, point-to-point broadcasts, including telephone and radio broadcast programs, became popular in 1920 and 1930.

The use of radio in the pre-war period was the development of detection and localization of aircraft and ships using radar. Today, there are many forms of radio, including wireless networks, mobile communications of all kinds, and radio broadcasting is to.

The main radio journalistic characteristics are auditive, auditory, or to be heard (for eyes only). Thus, radio journalistic works are sound, namely the voice of broadcasters, reporters, and news sources.

Because it is in the form of sound, the news written by radio reporters is also "voiced" or "told" (story telling). Consequently, radio news scripts (radio news scripts, radio copy) 
must be written using spoken language or oral language, which is a language commonly used in conversational style.

Journalism of audio visual in electronic media or broadcast television journalism, is a combination of verbal, visual, technological, and dramatic dimensions. Verbal, relating to words that are arranged in a concise, solid, effective. Visual, more emphasis on sharp language images, clear, lively, attractive. Technological, related to broadcast coverage, sound and image quality produced and received by receiving television sets in homes. Dramatical, means tangent to the aspects and dramatic values generated by the sequence of images produced simultaneously. This dramatic aspect does not have the radio mass media and newspapers.

The dramatic aspect of television combines three forces at once: the power of images, sounds and words. This is what is called concurrent effects and the simultaneous effect of television.

With the dramatic aspect, all sensory viewers work optimally. Communication experts often say, television has an extraordinary hypnotic power, so that emotions and behavior of audiences can easily move events that occur in the world, to the bedroom or to the viewer's living room when together (real time). All complete with emotion and other psychological aspects. The characteristic of a television is that the News Production must use spoken language, the language of the picture, describe the image and or report on the image. The use of this speech language has many implications, mainly because must be completely synchronized between images and words and or sentences. Television journalism is an activity of processing and broadcasting news carried out through television media. Journalists are also not merely referred to as journalists, they are broadcaster. There are producers, field reporters, there are cameramen, there are image editors, anchor news tones (news presenters).

\section{Conclusion}

Based on the results of the discussion in the paper, it can be concluded that journalism is the activity of preparing, seeking, collecting, processing, presenting, and disseminating news through the media periodically to the widest possible audience.

\section{References}

Budiman, Kris. 2005. "Dasar-Dasar Jurnalistik: Makalah yang disampaikan dalam Pelatihan Jurnalistik -- Info Java at 12th -15th Desember 2005.

Budiman, Kris. 2005. "Dasar-Dasar Jurnalistik: Makalah yang disampaikan dalam Pelatihan Jurnalistik -- Info Jawa 12th-15th Desember 2005. in www.infojawa.org.Ishwara, Luwi. 2005. "Catatan-Catatan Jurnalisme Dasar". Jakarta: Kompas.

Helena Olii, Reportase Radio, Pt Indeks Kelompok Gramedia, on Juny 2006

Onong Uchjana Effendi, Ilmu Komunikasi, PT Remaja Rosda Karya, on September 10 ${ }^{\text {th }}, 1984-2006$

Panuju, Redi. 2005. Nalar Jurnalistik. Malang: Bayu Media

Putra, R. Masri Sareb. 2006. "Teknik Menulis Berita dan Feature". Jakarta: Index

Sumadiria. Laris.2005. Jurnalistik Indonesia. Bandung: Simbiosa Pekatama Media

Wahyudi, J.B. 1996. Dasar-dasar Jurnalistik Radio dan Televisi. Jakarta: Pustaka Utama Grafiti.

Wibowo, Fred. 2007. Teknik Produksi Program Televisi. Yogyakarta: Pinus Book Publisher. 